\title{
Effects of larval diet on female reproductive output of the European coccinellid Adalia bipunctata and the invasive species Harmonia axyridis (Coleoptera: Coccinellidae)
}

\author{
Remy L. WARE ${ }^{1}$, Benjamin YGUEL ${ }^{2}$ and Michael E.N. MAJERUS ${ }^{1}$ \\ ${ }^{1}$ Department of Genetics, University of Cambridge, Downing Street, Cambridge CB2 3EH, UK; e-mail: r.ware@gen.cam.ac.uk, \\ m.majerus@gen.cam.ac.uk \\ ${ }^{2}$ Laboratoire d'Agro-écologie de l'ENFA, UMR 5174, Evolution et Diversité biologique, BP 22687, F-31326 Castanet-Tolosan \\ Cedex, France; e-mail: benyguel@hotmail.fr
}

Key words. Adalia bipunctata, aphidophagous guilds, cannibalism, Coccinellidae, Harmonia axyridis, intraguild predation, invasive species, larval diet, oviposition, ovariole number, reproductive fitness, resource competition

\begin{abstract}
Cannibalism and intraguild predation (IGP) are both common phenomena amongst aphidophagous coccinellids and serve as vital alternative feeding strategies which can prolong survival during periods of aphid scarcity. A reduction in essential prey density and the acceptance of conspecific or heterospecific prey are likely to have a considerable influence on both larval development and adult reproduction. However, little is known about the legacy of larval diet on adult performance. This paper considers the effects of the diet provided to larvae of Harmonia axyridis (Pallas) and Adalia bipunctata (Linnaeus) (Coleoptera: Coccinellidae) on the reproductive output of the resulting females. Results showed that larval diets, including treatments analogous to competition and IGP, did not affect adult longevity, ovipositional lag, proportion of eggs laid in clutches or ovariole number in $H$. axyridis or $A$. bipunctata. However, some variation in the maximum clutch size and oviposition rate was seen. A larval diet of unlimited aphids resulted in the largest clutches of eggs being laid by both species. The total number of eggs laid over 30 days was largest for $H$. axyridis when larvae were reared on unlimited aphids or limited aphids supplemented with either conspecific or heterospecific eggs, whereas oviposition was lower for A. bipunctata females that had received conspecific or heterospecific eggs in their larval diets. The results have also enabled us to make some general comparisons of reproductive parameters between the two species, and to refute the hypothesis that the maximum clutch size laid by a female ladybird is limited by the number of ovarioles within an ovary. We conclude that IGP of $A$. bipunctata eggs by H. axyridis larvae has a positive effect on reproductive output and is therefore likely to further contribute to the spread and increase of $H$. axyridis in Britain.
\end{abstract}

\section{INTRODUCTION}

There are broadly two types of prey utilised by coccinellids (Majerus \& Kearns, 1989; Majerus, 1994; Hodek, 1973, 1996). Essential prey supports immature growth, development and adult reproduction, whereas alternative prey merely maintains survival until essential prey items are located. Many principally aphidophagous species are known to accept a range of alternative foods during periods of aphid scarcity (Majerus, 1994). These may include immature stages of other aphidophages, an example of intraguild predation (IGP) (Polis et al., 1989), such as coccinellids, syrphids, and chrysopids (Majerus, 1994; Dixon, 2000). Other arthropod prey may also be accepted, such as lepidopteran eggs and larvae, adult craneflies, shield bugs and small beetles (Majerus, 1994). Reports of non-animal alternative foods eaten by carnivorous coccinellids include honeydew, pollen, nectar, plant sap and fungal spores (Majerus, 1994; Hodek, 1996). In addition to essential prey and the range of alternative foods listed above, cannibalism is a common phenomenon amongst aphidophagous coccinellids (Majerus \& Majerus, 1997; Dixon, 2000). Adults and larvae are known to predate members of their own species if their normal food becomes scarce (Majerus, 1994), and neo- nate larvae routinely eat unhatched eggs of their own clutch before dispersal (Banks, 1956). Such behaviour can be highly beneficial and provide young larvae with a significant survival advantage before locating their first aphid meal (Pienkowski, 1965; Majerus \& Majerus, 1997; Snyder et al., 2000).

Several authors have reported the benefits of a mixed diet containing both essential and alternative prey (Evans et al., 1999; Soares et al., 2004). Dietary generalism is likely to be extremely important in the persistence of species relying on ephemeral sources of essential food. Members of aphidophagous guilds are frequently faced with shortages in their usual prey, whose populations exhibit extreme density fluctuations in space and time (Dixon, 2000). The acceptance of alternative prey by aphidophagous coccinellids therefore enhances their ability to capitalize on short-lived and scattered opportunities as they seek out suitable sites in which to reproduce (Evans et al., 1999).

However, while the suitability of different diets for larval development, and the influence of food quality and quantity on adult reproduction have been well studied (Majerus, 1994; Evans et al., 1999; Dixon, 2000), there is little information available on the interaction between larval diet and adult diet. Several authors have reported 
on the relationship between larval and adult weight (Smith, 1965; Hukusima \& Ohwaki, 1972) but few have extended this to studies on fecundity. Michaud (unpubl.) has data showing that two types of aphid present in a mixed diet supplied to larvae of Coleomegilla maculata (De Geer) (Coleoptera: Coccinellidae) had effects on adult female fecundity and fertility, despite these females being fed on a monotypic diet when adult. That is, there was a "legacy of larval diet" on adult performance. This paper considers the effect of a variety of different diets fed to larvae on the reproductive output of female Harmonia axyridis (Pallas) and Adalia bipunctata (Linnaeus) (Coleoptera: Coccinellidae) fed unlimited aphids.

Diets were designed to mimic possible conditions experienced by coccinellids in the wild, such as the reduction in essential prey density caused by competition, and the acceptance of alternative foods, either via cannibalism or IGP. The study species used were chosen for two reasons. Firstly, the recent establishment of $H$. axyridis in Britain (Majerus et al., 2006a; Brown et al., 2008) has been met with considerable concern from entomologists (Majerus et al., 2006b). Predation of non-target species (Koch et al., 2003), competition with native aphidophages (Michaud, 2002) and IGP (Hironori \& Katsuhiro, 1997; Cottrell \& Yeargan, 1998) have all been reported from North America, where $H$. axyridis has been established since the late 1980s (Chapin \& Brou, 1991). Negative intraguild interactions between $H$. axyridis and native British species, such as $A$. bipunctata, are also predicted to occur, but their consequences have been little studied. Secondly, a comparison of the effects of competition and IGP between $H$. axyridis and $A$. bipunctata is of interest as both species have had a history of introductions to regions outside their native range, but with very different outcomes. Adalia bipunctata was first recorded in Japan in 1994 (Sakuratani, 1994) but has so far shown limited habitat use (Kajita et al., 2000). Conversely, H. axyridis has been introduced into North America and Europe, has established, spread and increased hugely, and is considered highly invasive (Koch, 2003; Roy et al., 2006). It has been suggested that the success of establishment and spread of introduced coccinellids is related to their ability to exploit native members of a guild, while avoiding exploitation themselves (Sato \& Dixon, 2004). Thus the contrasting invasion histories of $H$. axyridis and $A$. bipunctata could be due to a difference in the consequences of competition and IGP.

Ware et al. (in press) looked at the effects of competition and IGP experienced by larvae on survival, development and adult size of $A$. bipunctata and $H$. axyridis, and demonstrated a skew in the short-term consequences of IGP between them. The supplementation of a limited aphid diet with heterospecific eggs led to a significant advantage for $H$. axyridis in respect of larval development, survival and adult size, but gave no benefit to A. bipunctata. Here we investigate the effect of larval diet on the female reproductive output of the same individuals. Research into the consequences of IGP and competition on female reproductive fitness is urgently needed, as this subject is frequently ignored in studies limited to short-term outcomes. Furthermore, such a consideration is vital if we are to fully understand the impact of IGP on the spread and increase of an invasive species.

The results from the latter part of this work are discussed in the context of the debate over whether the maximum clutch size of a female ladybird is limited by the number of ovarioles she has in each ovary (Baungaard \& Hämäläinen, 1984; Stewart et al., 1991a, b; Dixon, 2000; but see Majerus, 1994).

\section{MATERIAL AND METHODS}

\section{Ladybird culturing protocol}

See Ware et al. (in press) for full details of culturing and rearing protocols. As the aforementioned paper considers fitness parameters that are often influenced by an individual's sex [such as adult size, development time and longevity (Majerus, 1994; Dixon, 2000)], comparisons were limited to those between female ladybirds only. In order to maximise the number of female offspring obtained from each matriline, we selected females that were known to be infected by a male-killing Spiroplasma. Larvae were derived from ten breeding pairs of Japanese $H$. axyridis (from Tokyo) and European A. bipunctata (from St. Petersburg). Individual pairs were housed in $9 \mathrm{~cm}$ Petri dishes and kept in the laboratory at $22^{\circ} \mathrm{C}$ under constant light. They were fed excess pea aphids, Acyrthosiphon pisum (Harris), daily, and eggs were collected daily prior to transfer of adults to a clean dish to induce oviposition (Majerus et al., 1989). Egg batches were then transferred to a constant environment room at $22^{\circ} \mathrm{C}, 35 \%$ humidity and $14 \mathrm{~L}: 10 \mathrm{D}$.

\section{Rearing of larvae}

Eggs that were to be provided as food for the larvae came from uninfected laboratory stocks of $H$. axyridis and A. bipunctata that had been breeding well for a period of 2-3 weeks. Thirty newly hatched larvae of each species were reared on one of four different feeding regimes: unlimited aphids $-\mathrm{A}$; limited aphids - B; a mixed diet of limited aphids and conspecific eggs - C; or a mixed diet of limited aphids and heterospecific eggs D. Precise details of these treatments are as follows:

A: Aphids ad libitum daily

B: Aphids day 1 , starvation days $2 \& 3$, aphids day 4, starvation days $5 \& 6$, aphids day 7 etc.

C: Aphids day 1, conspecific eggs days $2 \& 3$, aphids day 4, conspecific eggs days $5 \& 6$, aphids day 7 etc.

D: Aphids day 1, heterospecific eggs days $2 \& 3$, aphids day 4 , heterospecific eggs days $5 \& 6$, aphids day 7 etc.

Treatment $\mathrm{D}$ is considered analogous to when a low extraguild prey density experienced in the wild is supplemented with IGP. Treatment $\mathrm{C}$ acts as a control for comparison with treatment $\mathrm{D}$ to consider the different effects on fitness of conspecific and heterospecific eggs.

The number of eggs to be provided as food in treatments $\mathrm{C}$ and $\mathrm{D}$ were scaled for species of larva, larval instar, and species of egg, on the basis of results from preliminary investigations (Ware et al., in press). All eggs used were less than $48 \mathrm{~h}$ old and were carefully manipulated using a blunt mounted entomological pin. Numbers of eggs consumed each day (to the nearest half an egg) were recorded and any aphid or egg remains from the previous day were removed prior to supplying the new day's food. On days where treatment B larvae received no aphids, all aphid remains from the previous day were removed. Egg consumption, survival and development were monitored and newly eclosed adults were left without food for one day, before being 

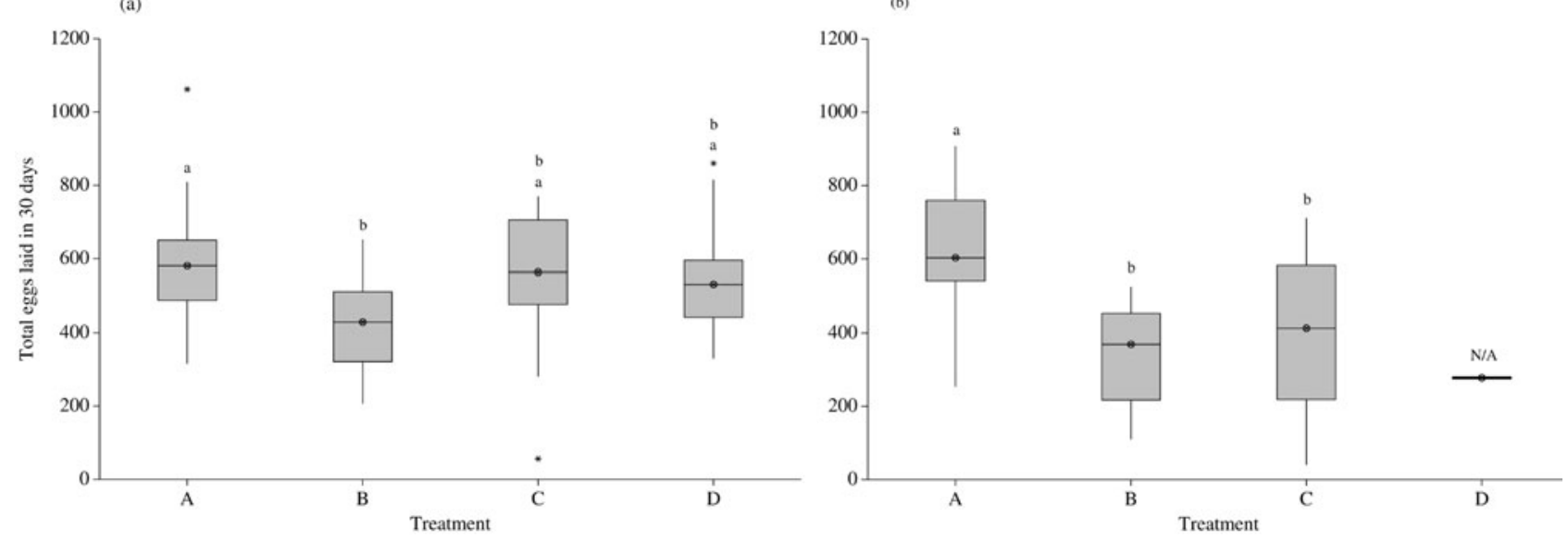

Fig. 1. Total eggs laid over 30 days by $H$. axyridis (a) and A. bipunctata (b) reared on different larval diets. A = unlimited aphids; $\mathrm{B}=$ limited aphids; $\mathrm{C}=$ limited aphids plus conspecific eggs; $\mathrm{D}=$ limited aphids plus heterospecific eggs. Analysis shows no significant difference between results marked with the same lower case letter ("N/A" refers to A. bipunctata treatment D, for which this analysis was not applicable due to small sample size). Medians (circles with stars), interquartile ranges (boxes), ranges (vertical lines) and outliers (stars) shown.

weighed, measured for maximum pronotal width and sexed (Ware et al., in press).

\section{Ovipositional data}

Females were transferred to clean $9 \mathrm{~cm}$ Petri dishes and fed excess aphids daily for 10 days before mating. To control for any male effects on a pair's reproductive fitness, the same male was alternated between each of the females reared on treatments $\mathrm{A}, \mathrm{B}, \mathrm{C}$ and $\mathrm{D}$ for each replicate number (thus A1, B1, C1 and D1 all received male 1; A2, B2, C2 and D2 all received male 2 etc.). This equated to each female receiving a male one day in four, and where a female was not yet old enough to be mated, or had not survived, the male was kept isolated until needed. All ladybirds were fed excess aphids daily and maintained in the laboratory at $22^{\circ} \mathrm{C}$ and constant light. Dishes were changed daily and any eggs retained. For each female, the time elapsed from the first addition of the male until she first laid eggs was recorded (hereafter referred to as "ovipositional lag"). Thereafter, the number of eggs laid per day, in tight clutches (where the eggs were nearly touching) / loose clutches / lines / or scattered, was counted carefully under a binocular dissecting microscope. Egg counting continued for 30 days and the maximum clutch size ("tight clutches" only) laid during this time was recorded. Ovipositional data from females that died within the 30 days were excluded from analysis. Surviving females were then given artificial food (Majerus \& Kearns, 1989) and clean dishes three times a week until their natural death.

\section{Ovariole number}

Upon their natural deaths, females were immediately placed in $100 \%$ ethanol in $0.5 \mathrm{ml}$ eppendorf tubes for 2 days prior to dissection, as preliminary studies showed that alcohol-treated specimens were easier to manipulate than freshly dead or desiccated individuals. The female's abdomen was removed by slicing under the metasternum using a scalpel blade. Fine entomological tools were used to cut open the abdomen and carefully tease away the abdominal tissue from the exoskeleton. Phosphate-buffered saline (PBS) (Gibco PBS $1 \times \mathrm{pH} 7.4-$ $\mathrm{CaCl}_{2}, \mathrm{MgCl}_{2}$ ) was used to re-hydrate the tissue. A few drops of toludine blue solution (Fisher Scientific general purpose grade) were added to the tissue and left for $2 \mathrm{~min}$. Excess stain was then absorbed with filter paper and the tissue rinsed in a few drops of PBS. The female's reproductive organs were located by viewing under a binocular dissecting microscope, and the ovaries separated from the rest of the tissue. Each ovary was examined separately, and ovarioles were counted by carefully removing and destroying each one in turn using fine mounted entomological pins. The larger of the two ovariole counts obtained for each individual was used in further analysis. Not all dissections were successful due to severe desiccation and/or autolysis of the ladybirds, and hence ovariole counts were lacking for some individuals.

\section{Statistical analysis}

All statistical analyses and manipulations were carried out using Minitab 14. All data were subjected to non-parametric analysis, as sample size was highly variable and particularly low for some treatments, and Kolmogorov-Smirnov tests revealed a significant difference from a normal distribution within some datasets. Longevity, ovipositional lag, oviposition rate, maximum clutch size, proportion of eggs laid in clutches and ovariole number were all analysed using Kruskal-Wallis and repeated pairwise Mann-Whitney $\mathrm{U}$ tests adjusting for ties, with significant results assessed at Bonferroni corrected alpha values (referred to in the text as $\alpha \mathrm{B}$ ). The correlation between maximum clutch size and maximum ovariole number of an individual was analysed using a Spearman rank correlation. Treatments are referred to as A / B / C / D in details of statistical tests. While the overriding variable we wished to consider was the effect of larval diet within a species, we also wanted to make some general comparisons between the two species with respect to the different parameters assessed. Where no difference was found between treatments within a species, all data were pooled for between-species comparisons. Where treatment was found to have a significant effect, comparisons between species were limited to treatment A only, to give an idea of the relative magnitude of the different parameters in both species when fed an optimal diet.

\section{RESULTS}

\section{Longevity}

There was no significant difference in longevity between $H$. axyridis adult females that had been reared under different treatments as larvae (Kruskal-Wallis test: A-B-C-D: $\mathrm{H}=0.88,3$ d.f., $\mathrm{p}=0.831$, median range $=$ 
(a)

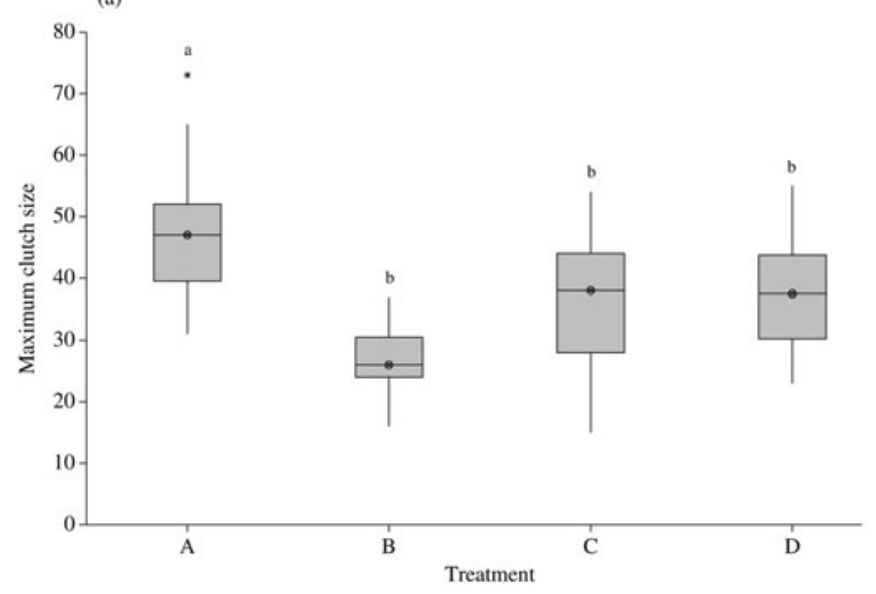

(b)

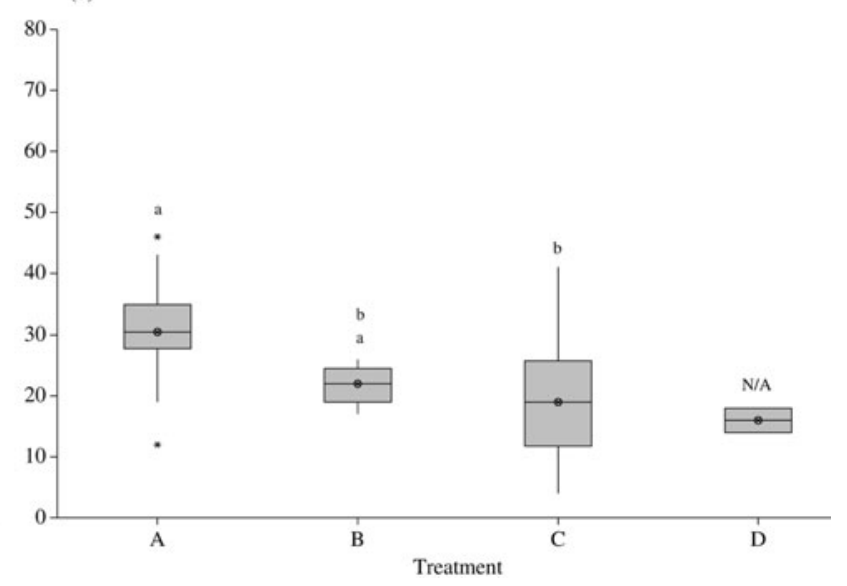

Fig. 2. Maximum clutch size laid in 30 days by $H$. axyridis (a) and $A$. bipunctata (b) reared on different larval diets. A $=$ unlimited aphids; $\mathrm{B}=$ limited aphids; $\mathrm{C}=$ limited aphids plus conspecific eggs; $\mathrm{D}=$ limited aphids plus heterospecific eggs. Analysis shows no significant difference between results marked with the same lower case letter ("N/A" refers to A. bipunctata treatment D, for which this analysis was not applicable due to small sample size). Medians (circles with stars), interquartile ranges (boxes), ranges (vertical lines) and outliers (stars) shown.

119.5-140.5). This was also the case for A. bipunctata (Kruskal-Wallis test: A-B-C-D: $\mathrm{H}=1.08,3$ d.f., $\mathrm{p}=$ 0.782 , median range $=74.0-118.0)$. Harmonia axyridis females survived significantly longer (median $=133$ days) than $A$. bipunctata females (median $=86$ days) (Mann-Whitney $\mathrm{U}$ test on pooled data: $\mathrm{W}=5219.5, \mathrm{p}=$ 0.003).

\section{Ovipositional lag}

The period of time that elapsed between a female first receiving a male, and her first eggs being laid was similar for $H$. axyridis under all treatments (Kruskal-Wallis test: A-B-C-D: $H=1.09,3$ d.f., $p=0.780$, median $=2.0$ for all treatments). There was also no significant difference in the duration of this period between treatments for $A$. bipunctata (Kruskal-Wallis test: A-B-C-D: $\mathrm{H}=4.10,3$ d.f., $\mathrm{p}=0.251$, median range $=14.0-19.5)$. However, $A$. bipunctata females took significantly longer to begin egglaying after the introduction of a male (median $=18$ days) than did $H$. axyridis females (median $=2$ days) (MannWhitney U test on pooled data: $\mathrm{W}=2928.5, \mathrm{p}<0.001$ ).

\section{Total oviposition over 30 days}

There was some heterogeneity with respect to treatment in the total number of eggs laid by $H$. axyridis females over 30 days (Kruskal-Wallis test: $\mathrm{A}-\mathrm{B}-\mathrm{C}-\mathrm{D}$ : $\mathrm{H}=8.02$, $\mathrm{p}=0.046$, median range $=429.0-580.5$ ) (Fig. 1a). Further analysis revealed that the only significant difference lay between treatments $\mathrm{A}$ and $\mathrm{B}$, with treatment $\mathrm{A}$ females laying a greater number of eggs than treatment $B$ females (Mann-Whitney $U$ test: $\alpha \mathrm{B}=0.008$ (6 tests): $\mathrm{A}-\mathrm{B}: \mathrm{W}=609.0, \mathrm{p}=0.007)$. All other pairwise comparisons were non-significant at the corrected alpha value (Mann-Whitney U tests: $\alpha \mathrm{B}=0.008$ (6 tests): $\mathrm{A}-\mathrm{C}: \mathrm{W}=$ 706.0, $\mathrm{p}=0.911$; $\mathrm{A}-\mathrm{D}: \mathrm{W}=678.0, \mathrm{p}=0.247$; $\mathrm{B}-\mathrm{C}: \mathrm{W}=$ 92.0, $\mathrm{p}=0.033$; $\mathrm{B}-\mathrm{D}: \mathrm{W}=82.0, \mathrm{p}=0.051 ; \mathrm{C}-\mathrm{D}: \mathrm{W}=$ 421.0, $\mathrm{p}=0.510)$.

Treatment D $A$. bipunctata females were excluded from analysis of ovipositional data due to small sample size: data was only available from two females (these data are shown in the accompanying figures for reference). There was significant variation in the total number of eggs laid over 30 days by females of the other treatments (KruskalWallis test: A-B-C: $\mathrm{H}=11.25,2$ d.f., $\mathrm{p}=0.004$, median range $=413.0-603.0$ ) (Fig. 1b), with treatment $\mathrm{A}$ females laying significantly more eggs than treatment $\mathrm{B}$ or treatment $\mathrm{C}$ females (Mann-Whiney $\mathrm{U}$ tests: $\alpha \mathrm{B}=0.017$ (3 tests): $\mathrm{A}-\mathrm{B}: \mathrm{H}=170.0, \mathrm{p}=0.006 ; \mathrm{A}-\mathrm{C}: \mathrm{H}=306.0, \mathrm{p}=$ $0.005)$. However, there was no significant difference in the total number of eggs laid between treatment $\mathrm{B}$ and treatment $\mathrm{C}$ females (Mann-Whiney $\mathrm{U}$ test: $\alpha \mathrm{B}=0.017$ (3 tests): $\mathrm{B}-\mathrm{C}: \mathrm{H}=413.0, \mathrm{p}=0.628)$.

Where larvae were reared on unlimited aphids, the total number of eggs laid over 30 days was similar for $H$. axyridis and $A$. bipunctata (medians of 581 and 603 eggs respectively) (Mann-Whitney $\mathrm{U}$ test: $\mathrm{A}-\mathrm{A}: \mathrm{W}=564.0, \mathrm{p}$ $=0.317$ ).

\section{Proportion of eggs laid in clutches}

There was no significant difference in the proportion of eggs laid in clutches ("tight clutches") between treatments for either species (Kruskal Wallis tests: A-B-C-D: $\mathrm{H}=$ 3.44, 3 d.f., $\mathrm{p}=0.329$, median range $=0.81-0.86$ for $H$. axyridis and $\mathrm{A}-\mathrm{B}-\mathrm{C}: \mathrm{H}=2.99,2$ d.f., $\mathrm{p}=0.225$, median range $=0.72-0.89$ for $A$. bipunctata). However, $H$. axyridis females laid a significantly higher proportion of their eggs in clutches than did A. bipunctata females (medians of $84.6 \%$ and $77.5 \%$ respectively) (MannWhitney $\mathrm{U}$ test on pooled data: $\mathrm{W}=4691.0, \mathrm{p}=0.004)$.

\section{Maximum clutch size}

The maximum clutch size laid by $H$. axyridis females showed significant variation with respect to which diet the females received as larvae (Kruskal-Wallis test: A-B-C-D: $\mathrm{H}=26.21,3$ d.f., $\mathrm{p}<0.001$, median range $=$ 26.0-47.0) (Fig. 2a). Further analysis showed that females reared under treatment $A$ achieved a higher maximum clutch size than females reared under the other 
(a)

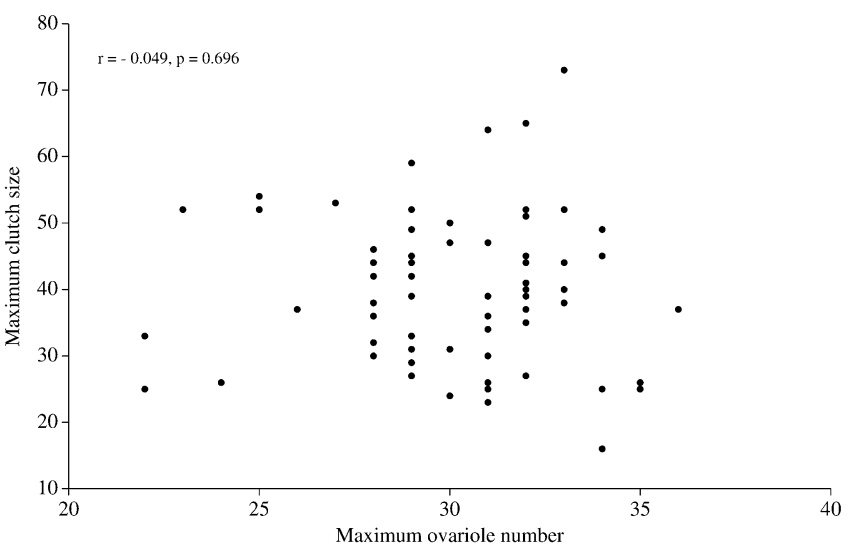

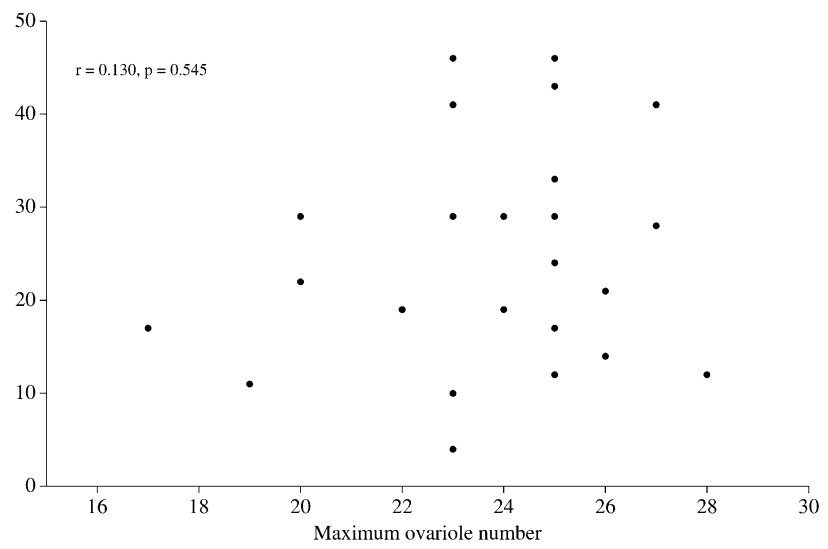

Fig. 3. Correlation between the maximum clutch size and the maximum ovariole number of H. axyridis (a) and $A$. bipunctata (b). Data pairs are pooled from all treatments. "r" indicates Spearman rank correlation coefficient. N.B. Different scales for (a) an d (b).

three treatments (Mann-Whitney $\mathrm{U}$ tests: $\alpha \mathrm{B}=0.008(6$ tests): $\mathrm{A}-\mathrm{B}: \mathrm{W}=652.5, \mathrm{p}<0.001 ; \mathrm{A}-\mathrm{C}: \mathrm{W}=855.5, \mathrm{p}=$ $0.002 ; \mathrm{A}-\mathrm{D}: \mathrm{W}=755.0, \mathrm{p}=0.002)$. Treatment $\mathrm{B}$ females showed no statistically significant difference in maximum clutch size to treatment $\mathrm{C}$ or $\mathrm{D}$ females (Mann-Whitney U tests: $\alpha \mathrm{B}=0.008$ (6 tests): $\mathrm{B}-\mathrm{C}: \mathrm{W}=82.5, \mathrm{p}=0.011$; $\mathrm{B}-\mathrm{D}: \mathrm{W}=72.5, \mathrm{p}=0.013)$, and treatment $\mathrm{C}$ and $\mathrm{D}$ females were also similar to each other in respect of this parameter (Mann-Whitney U test: $\alpha \mathrm{B}=0.008$ (6 tests): $\mathrm{C}-\mathrm{D}: \mathrm{W}=409.5, \mathrm{p}=0.759)$.

The maximum clutch size laid by $A$. bipunctata females also varied with the diet experienced at the larval stage (Kruskal-Wallis test: $\mathrm{A}-\mathrm{B}-\mathrm{C}: \mathrm{H}=12.65,2$ d.f., $\mathrm{p}=$ 0.002 , median range $=19.0-30.5$ ) (Fig. 2b). Further analysis showed that treatment $\mathrm{A}$ females laid a higher maximum clutch size than treatment $\mathrm{C}$ females (MannWhitney U test: $\alpha \mathrm{B}=0.017$ (3 tests): $\mathrm{A}-\mathrm{C}: \mathrm{W}=317.5$, $\mathrm{p}$ $=0.001)$. However, there was no statistically significant difference in maximum clutch size between treatments $A$ and $\mathrm{B}$ (Mann-Whitney $\mathrm{U}$ test: $\alpha \mathrm{B}=0.017$ (3 tests): $\mathrm{A}-\mathrm{B}$ : $\mathrm{W}=166.0, \mathrm{p}=0.018)$ or $\mathrm{B}$ and $\mathrm{C}$ (Mann-Whitney $\mathrm{U}$ test: $\alpha \mathrm{B}=0.017$ (3 tests): $\mathrm{B}-\mathrm{C}: \mathrm{W}=71.0, \mathrm{p}=0.432$ ).

Harmonia axyridis had a significantly larger maximum clutch size under treatment A (median $=47$ eggs) than did A. bipunctata (median $=31$ eggs) (Mann-Whitney $U$ test: A-A: $\mathrm{W}=761, \mathrm{p}<0.001)$.

\section{Ovariole number}

The larger of the two ovariole counts taken per individual was similar for all $H$. axyridis females, regardless of the larval diet upon which they were reared (KruskalWallis test: A-B-C-D: $\mathrm{H}=5.04,3$ d.f., $\mathrm{p}=0.169$, median range $=29.0-31.5)$. For $A$. bipunctata, ovariole counts were only available for three treatment B females and two treatment D females, and these treatments were therefore excluded from analysis. There was no significant difference in the largest ovariole number between $A$. bipunctata females reared on treatments A and C (MannWhitney U test: $\mathrm{W}=142.0, \mathrm{p}=0.551$, medians of 25.0 and 23.5 respectively). The maximum ovariole number was larger in $H$. axyridis females (median $=31$ ovarioles per ovary) than $A$. bipunctata females (median $=24$ ovarioles per ovary) (Mann-Whitney U test on pooled data: $\mathrm{W}=4239.0, \mathrm{p}<0.001)$.

\section{Correlation between maximum clutch size and ovariole number}

In both $H$. axyridis and $A$. bipunctata, the maximum clutch size laid by an individual was often vastly in excess of the maximum ovariole number. Furthermore, no significant correlation was found between the maximum ovariole number and the maximum clutch size (Spearman rank correlation: $\mathrm{r}_{\mathrm{s}}=-0.049, \mathrm{p}=0.696$ for $H$. axyridis and $\mathrm{r}_{\mathrm{s}}=0.130, \mathrm{p}=0.545$ for A. bipunctata) (Fig. 3).

\section{DISCUSSION}

This study has allowed an assessment of the consequences that the diet available to coccinellid larvae has on the reproductive fitness of the resulting adults. For both $H$. axyridis and $A$. bipunctata, the maximum clutch sizes were laid by females that had been reared on unlimited aphids. Clutch size and oviposition rate is known to be influenced by the diet available to females at the time of oviposition (Ibrahim, 1955; Ghanim et al., 1984; Dixon \& Guo, 1993; Dixon, 2000), but it is evident from the results presented here that the diet experienced during immature growth and development is also important, even when adult diet is optimal. Dixon \& Guo (1993) suggest that this is due to the effect of larval food supply on adult size and ovariole number. While the results of this paper and Ware et al. (in press) support the former suggestion, there is no evidence of larval diet affecting ovariole number.

When considering the reproductive output of females, in terms of the total number of eggs laid over 30 days, it is clear that the different diets had quite different effects in $H$. axyridis compared to A. bipunctata. Harmonia axyridis exhibited similar high rates of oviposition when reared under the unlimited aphid diet, and under the mixed diets containing either conspecific or heterospecific eggs. Conversely, A. bipunctata females had much lower outputs when their larval diets were of a mixed nature, whether they contained conspecific or heterospecific eggs. Considering that two further parameters that 
might be expected to influence the lifetime reproductive success of a female, longevity and ovariole number, remained constant under the different larval diets in both species, the higher fecundities of treatment A, B and $\mathrm{C} H$. axyridis females and treatment A A. bipunctata females presumably represent a more efficient conversion of aphid biomass into egg biomass. This suggests that while A. bipunctata performs best as a specialist of aphids, $H$. axyridis is able to perform equally well on aphids alone or a mixed diet including aphids. It should, however, be noted that this study only followed oviposition for 30 days, and lifetime fecundity should, ideally, be measured, as oviposition rate is known to vary over time (Majerus, 1994; Dixon, 2000).

Some general conclusions can be drawn from comparisons between the results obtained for $H$. axyridis and $A$. bipunctata. Clearly $H$. axyridis is the larger of the two species, and the larger median maximum clutch size and the larger median ovariole number of $H$. axyridis supports the hypotheses that larger ladybirds lay larger clutches and have more ovarioles (Rhamhalinghan, 1985; Dixon, 2000).

Another interesting difference observed between the two species was that $A$. bipunctata females took considerably longer to begin ovipositing after first receiving a male than did $H$. axyridis females. Majerus (1994) reports that female ladybirds only accept males after feeding on appropriate food. However, as all individuals of both species received unlimited aphids, the difference is unlikely to be due to diet experienced during adulthood. Temperature and day length are also known to influence oviposition behaviour (Dixon, 2000), and it could have been that the temperature and light regime used was less favourable for A. bipunctata oviposition than for $H$. axyridis oviposition. This would require further investigation. It is known that $A$. bipunctata females are highly promiscuous and multiple mating is thought to be beneficial in promoting sperm competition (Majerus, 1994) and reducing genetic incompatibility (Haddrill, 2001). Less is known about genetic incompatibility within $H$. axyridis, although it is also a highly promiscuous species (R. Ware, pers. obs.). In this study, females were only ever supplied with one male and it could be that $A$. bipunctata females were more reluctant to mate or oviposit under a single male treatment than were $H$. axyridis females. The fact that $H$. axyridis laid a greater proportion of its eggs in clutches may have indicated that a greater proportion of its eggs were fertile, as single or scattered eggs often do not hatch (R. Ware \& M. Majerus, pers. obs.). Unfortunately, egg fertility was not monitored in this study so it is not possible to provide definitive evidence of the above suggestion. Further work into this area would be of interest.

Finally, the data collected within this study can contribute to the debate over the correlation between ovariole number and clutch size in coccinellids. Baungaard \& Hämäläinen (1984) attest that the number of ovarioles in a single ovary limits the maximum clutch size that a female can lay, since only the most fully developed egg within an ovariole can be laid, and all eggs in a clutch originate from the same ovary. Stewart et al. (1991a, b) and Dixon (2000) agree with this prediction. However, Majerus (1994) reports observations of egg clutches from A. bipunctata and C. septempunctata, both in the laboratory and the field, which contain numbers well in excess of the maximum number of ovarioles recorded for these species. Baungaard \& Hämäläinen (1984) argue that such "superbatches" are the result of a second round of oviposistion being made in very close proximity to the first, whereas Majerus (1994) suggests that a clutch may include eggs from both ovaries and more than one egg may be deposited from one ovariole. The results of this study also report maximum clutch sizes that greatly exceed the maximum ovariole number of the female that laid them. In $H$. axyridis the maximum clutch size recorded in the study was 73 , and the larger of the two ovariole counts of this female was 33. The largest $A$. bipunctata egg clutch contained 46 eggs but only 23 ovarioles were found in the female's largest ovary. Furthermore, whereas Dixon (2000) states that females with more ovarioles lay larger clusters of eggs, the results presented here show no correlation between clutch size and ovariole number. These results thus support the view of Majerus (1994) that egg clutches may contain eggs from both ovaries, and, for $H$. axyridis at least, that a clutch may contain more than one egg from an individual ovariole.

In conclusion, this study provides evidence of legacies of larval diet on adult performance, and demonstrates that larval IGP can have positive effects on $H$. axyridis reproductive output, whereas little benefit is evident for $A$. bipunctata females. Ware et al. (in press) presented similar effects of IGP on larval development, survival and adult size. The ability of $H$. axyridis to capitalise on various alternative food sources, including other members of its guild, is considered partly responsible for its extensive invasion history and disastrous consequences for native species (Koch et al., 2003; Roy et al., 2006). In stark contrast is the limited spread of $A$. bipunctata in Japan, which may be attributable both to its propensity to act as intraguild prey and its lower ability to exploit other guild members (Kajita et al., 2000).

ACKNOWLEDGEMENTS. The authors wish to acknowledge the help of I. Wright, S. Elnagdy, S. Saeed, S. Koyama and L.-J. Michie at the Department of Genetics Field Station, University of Cambridge, UK. We would also like to thank Y. Obara, T. Satoh and S. Koyama, from the Tokyo University of Agriculture and Technology, for help with collections and facilities in Japan. Many thanks also to F. Balloux from the Department of Genetics, University of Cambridge, UK for advice on statistical techniques.

\section{REFERENCES}

BANKS C.J. 1956: Observations on the behaviour and mortality in Coccinellidae before dispersal from the eggshells. Proc. R. Soc. Lond. (A) 31: 56-61.

BAUNGAARD J. \& HÄMÄLÄINEN M. 1984: Notes on egg-batch size in Adalia bipunctata (Coleoptera, Coccinellidae). Ann. Entomol. Fenn. 47: 25-27. 
Brown P.M.J., Roy H.E., Rotheray P., Roy D.B., Ware R.L. \& Majerus M.E.N. 2008: Harmonia axyridis in Great Britain: analysis of the spread and distribution of a non-native coccinellid. BioControl 53: 55-67.

Chapin J.B. \& Brou V.A. 1991: Harmonia axyridis (Pallas), the third species of the genus to be found in the United States (Coleoptera: Coccinellidae). Proc. Entomol. Soc. Wash. 93 630-635.

Cottrell T.E. \& YeArgan K.V. 1998: Intraguild predation between an introduced lady beetle Harmonia axyridis (Coleoptera: Coccinellidae) and a native lady beetle Coleomegilla maculata (Coleoptera: Coccinellidae). J. Kans. Entomol. Soc. 71: $159-163$.

Dixon A.F.G. 2000: Insect Predator-Prey Dynamics: Ladybird Beetles \& Biological Control. Cambridge University Press, Cambridge, $257 \mathrm{pp}$.

Dixon A.F.G. \& Guo Y. 1993: Egg and cluster size in ladybird beetles (Coleoptera: Coccinellidae): The direct and indirect effects of aphid abundance. Eur. J. Entomol. 90: 457-463.

Evans E.W., Stevenson A.T. \& Richards D.R. 1999: Essential versus alternative foods of insect predators: benefits of a mixed diet. Oecologia 121: 107-112.

Ghanim A.E.-B., Freier B. \& Wetzel T. 1984: Zur Nahrungsaufnahme und Eiablage von Coccinella septempunctata L. bei unterschiedlichem Angebot von Aphiden der Arten Microsiphum avenae (Fabr.) und Rhopalosiphum padi (L.). Arch. Phytopathol. PflSch. 20: 117-125.

HadDRILL P.R. 2001: The Development and Use of Molecular Genetic Markers to Study Sexual Selection and Population Genetics in the 2-spot Ladybird, Adalia bipunctata (L.). $\mathrm{PhD}$ Thesis, University of Cambridge.

Hironori Y. \& Katsuhiro S. 1997: Cannibalism and interspecific predation in two predatory ladybirds in relation to prey abundance in the field. Entomophaga 42: 153-163.

Hodek I. 1973: Biology of Coccinellidae. Academia, Prague \& Junk, The Hague, 316 pp.

Hodek I. 1996: Food relationships. In Hodek I. \& Honěk A. (eds): Ecology of Coccinellidae. Kluwer Academic Publishers, Dordrecht, 484 pp.

Hukusima S. \& OHWaKi T. 1972: Further notes on feeding biology of Harmonia axyridis Pallas (Coleoptera: Coccinellidae). Res. Bull. Fac. Agric. Gifu Univ. 33: 75-82.

IвRAнiм M.M. 1955: Studies on Coccinella undecimpunctata aegyptiaca Reiche. 2. Biology and life history. Bull. Soc. Entomol. Egypte 39: 395-423.

Kajita Y., Takano F., Yasuda H. \& Agarwala B.K. 2000: Effects of indigenous ladybird species (Coleoptera: Coccinellidae) on the survival of an exotic species in relation to prey abundance. Appl. Entomol. Zool. 35: 473-479.

Koch R.L. 2003: The multicoloured Asian lady beetle, Harmonia axyridis: A review of its biology, uses in biological control and non-target impacts. J. Insect Sci. 3.32: 1-16.

Koсh R.L., Hutchinson W.D., Venette R.C. \& Heimpel G.E. 2003: Susceptibility of immature monarch butterfly, Danaus plexippus (Lepidoptera: Nymphalidae: Danainae), to predation by Harmonia axyridis (Coleoptera: Coccinellidae). Biol. Control 28: 265-270.

Majerus M.E.N. 1994: Ladybirds. New Naturalist Series No. 81. Harper Collins, London, 320 pp.
Majerus M.E.N. \& Kearns P.W.E. 1989: Ladybirds. Naturalists' Handbook Series No. 10. Richmond Publishing, Slough, $116 \mathrm{pp}$.

Majerus M.E.N. \& Majerus T.M.O. 1997: Cannibalism among ladybirds. Bull. Amat. Entomol. Soc. 56: 235-248.

Majerus M.E.N., Mabвott P., Rowland F. \& Roy H.E. 2006a: The harlequin ladybird, Harmonia axyridis, arrives in Britain. Entomol. Mon. Mag. 142: 87-92.

Majerus M.E.N., Strawson V. \& Roy H.E. 2006b: The potential impacts of the arrival of the Harlequin ladybird, Harmonia axyridis (Pallas) (Coleoptera: Coccinellidae), in Britain. Ecol. Entomol. 31: 207-215.

Michaud J.P. 2002: Invasion of the Florida citrus ecosystem by Harmonia axyridis (Coleoptera: Coccinellidae) and asymmetric competition with a native species, Cycloneda sanguinea. Environ. Entomol. 31: 827-835.

PIENKOWSKI R.L. 1965: The incidence and effect of egg cannibalism in first-instar Coleomegilla maculata lengi (Coleoptera: Coccinellidae). Ann. Entomol. Soc. Am. 58: 150-153.

Polis G.A., Myers C.A. \& Holt R.D. 1989: The ecology and evolution of intraguild predation: potential competitors that eat each other. Annu. Rev. Ecol. Syst. 20: 297-330.

RHAMHALINGHAN M. 1985: Intraspecific variations in ovariole numbers/ovary in Coccinella septempunctata L. (Coleoptera: Coccinellidae). The Indian Zool. 9: 91-97.

Roy H.E., Brown P.M.J. \& Majerus M.E.N. 2006: Harmonia axyridis: A successful biocontrol agent or an invasive threat? In Eilenberg J. \& Hokkanen H. (eds): An Ecological and Societal Approach to Biological Control. Kluwer Academic Publishers, Dordrecht, $322 \mathrm{pp}$.

SakURATANi Y. 1994: New record of Adalia bipunctata (Linnaeus) (Coleoptera: Coccinellidae) from Japan. Jpn. J. Appl. Entomol. Zool. 62: 627-628.

Sato S. \& Dixon A.F.G. 2004: Effect of intraguild predation on the survival and development of three species of aphidophagous ladybirds: consequences for invasive species. Agric. Forest Entomol. 6: 21-24.

Sмiтн B.C. 1965: Differences in Anatis mali Auct. and Coleomegilla maculata lengi Timberlake to changes in the quality and quantity of larval food. Can. Entomol. 97: 1159-1166.

Snyder W.E., Joseph S.B., Preziosi R.F. \& Moore A.J. 2000: Nutritional benefits of cannibalism for the lady beetle Harmonia axyridis (Coleoptera: Coccinellidae) when prey quality is poor. Environ. Entomol. 29: 1173-1179.

Soares A.O., Coderre D. \& Schanderl H. 2004: Dietary selfselection behaviour by the adults of the aphidophagous ladybeetle Harmonia axyridis (Coleoptera: Coccinellidae). $J$. Anim. Ecol. 73: 478-486.

Stewart L.A., Dixon A.F.G., Rưžıcka Z. \& Iperti G. 1991a: Clutch and egg size in ladybird beetles. Entomophaga 36: 329-333.

Stewart L.A., Hemptinne J.-L. \& Dixon A.F.G. 1991b: Reproductive tactics of ladybird beetles: Relationships between egg size, ovariole number and developmental time. Funct. Ecol. 5: 380-385.

Ware R.L., YGuel B. \& Majerus M.E.N. (in press): Effects of intraguild predation and competition on larval development of the European coccinellid Adalia bipunctata and the invasive species Harmonia axyridis. Ecol. Entomol.

Received October 9, 2007; revised and accepted December 20, 2007 